\title{
Artvin İlinde Fasulye Biyoçeşitliliği
}

\author{
*Ömer SÖZEN ${ }^{1}$ \\ Hatice BOZOĞLU² \\ ${ }^{1}$ Ahi Evran Üniversitesi Ziraat Fakültesi Tarımsal Biyoteknoloji Bölümü, Kırşehir \\ ${ }^{2}$ Ondokuzmayıs Üniversitesi Ziraat Fakültesi Tarla Bitkileri Bölümü, Samsun \\ *Sorumlu yazar e-posta (Corresponding author; e-mail): eekim_55@hotmail.com
}

Geliş tarihi (Received): 10.01.2013 Kabul tarihi (Accepted): 26.04.2013

\section{Öz}

Bünyesinde 7 tane barajın yapılmasına karar verilen ve bunlardan bir kısmının inşaatının tamamlandığı Artvin İli'nin su altında kalacak alanları başta olmak üzere ilin genelindeki mevcut yerel fasulye populasyonlarının toplanarak çeşitliliğinin belirlenmesi amacıyla bu çalışma yürütülmüştür. Çalışma için 2004 yılında bir ön gezi, 2005 yılında ise tohum toplama gezisi yapılmıştır. 7 ilçedeki 74 köy gezilmiş 279 noktadan fasulye tohum örneği ile fasulye tarımının durumunu belirlemek için bilgi toplanmıştır. Toplanan tohumlar, tohum şekli ve rengi/renkleri dikkate alınarak 400 adet alt örneğe ayrılmıştır. Tohum rengi ve şekli bile bölgenin çeşitlilik açısından ne kadar zengin olduğunun ipuçlarını vermiştir. Toplanan bilgilerden fasulyenin hemen her köyde ve her çiftçi tarafından küçük alanlarda yetiştirildiği, ticari çeşit girişinin olmadığı ve çoğu materyalin yerel olduğu sonucu çıkarılmıştır. Özellikle merkez ilçeye bağlı Ortaköy (Berta)'de yetiştirilen kuru fasulyenin ülkenin en önemli lokantalarına satıldığı ve fasulyenin mısır, patates ile birlikte bölgenin en önemli tarla bitkilerinden biri olduğu görülmüştür.

Anahtar Kelimeler: Artvin, yerel fasulye çeşitleri, karakterizasyon, baraj, survey

\section{Bean Bio-Diversity in Artvin Province}

\begin{abstract}
This study was conducted in order to collect the current domestic bean populations and determine their diversity in Artvin Province (especially areas that will be submerged under water after completion of 7 dams, construction of some of which are already completed). For the study, an initial visit was made in 2004 and in 2005 a seed collection travel was conducted. 74 villages in 7 provinces were visited to collect bean seed samples from 279 sites in order to determine the status of bean agriculture and also gather information about the bean agriculture. The collected seeds were separated into 400 sub samples considering shape and color/colors. Seed color and shape give clue about the diversity of the region with this respect. It was understood from the collected information that bean is grown in almost every village and by every farmer in small areas, that there is no commercial variety entrance and that most of the materials are of local origin. It was especially realized that bean grown in Ortaköy (Berta) which is affiliated to central province is being sold to the most important restaurants of the country and that dry bean is one of the most important field plants of the region together with patato and corn.
\end{abstract}

Keywords: Artvin, bean landraces, characterization, dam, survey

\section{Giriş}

E asulye (Phaseolus vulgaris L.), ülkemizin hemen her tarafında kuru tane ya da taze amaçlı yetiştirilebilen ve özellikle de Karadeniz Bölgesi'nde geniş varyasyon göstermiş bir baklagil bitkisidir. Tanelerinde bulunan yüksek protein (\% 22.6), karbonhidrat (\% 56), mineral madde ve vitaminlerce zenginliği kuru fasulyeyi ülkemizde önemli bir tarım ürünü haline getirmiştir (Akçin 1988).

Kuru fasulye, yemeklik tane baklagiller içinde ekim alanı (29.2 milyon ha) ve üretim (23.2 milyon ton) miktarı bakımından dünyada ilk sırada olmasına rağmen, ülkemizde 94.625 ha ekim alanı ve 200.673 ton üretimi ile nohut ve mercimekten sonra üçüncü sırada kendine yer bulmuştur (Anonim 2011). Karadeniz Bölgesi ise 32.069 ha alandan elde edilen 26.080 ton üretim ile kuru fasulye üretiminin \% 13'lük payını karşılamaktadır (TÜİK 2011).

Artvin İli, Karadeniz Bölgesi'nin doğusunda yer alan, Karadeniz'e kıyısı bulunan bir ilimizdir. Coğrafi ve topoğrafik yapısındaki farklılıklar nedeniyle Hopa ve Arhavi ilçelerindeki deniz seviyesindeki arazilerden Şavşat, Ardanuç ve Yusufeli ilçelerinin yayla ve mezralarındaki yaklaşık $2.000 \mathrm{~m}$ rakımlı arazilere kadar tarımsal faaliyet yapılabilmektedir.

İlin toplam tarım arazisi 64.200 ha olup, il yüzölçümünün \% 9'u tarım arazileri, \% 15'i de çayır-mera arazilerinden meydana gelmiştir. Tarım arazilerinin \% 5.38' ini çay, \% 3.55'ini 
tahıllar, \% 2.97'sini diğer tarla ürünleri geri kalan araziyi ise sebze, meyve, bağ, fındık, zeytin alanları oluşturmaktadır. Tarla ürünleri 4.894 ha alanda ekilmekte olup, en çok mısır, patates, fasulye ve yem bitkileri yetiştiriciliği yapılmaktadır. Kuru fasulye 355 ha ekim alanı ve 1.590 ton üretim değerine sahiptir (Artvin Tarım İ Müdürlüğü 2011).

Artvin İli'nde tarım geleneksel yöntemlerle yapılmakta olup işletmelerin büyük kısmı hayvansal ve bitkisel üretimi bir arada yapmaktadır. Üretim ticari amaçtan çok aile ihtiyacını karşılamaya dönüktür. Halk ürettiği ürünlerin \%70'ini kendi tüketmekte \% 30'una yakınını ise mahalli pazarlara göndermektedir. Tarla ürünlerinin bir kısmında kontrollü ve sertifikalı tohum kullanımı olmayıp genelde çiftçiler kendi tohumluklarını ayırmakta ya da pazarlarda açıkta satılan tohumları kullanmaktadırlar (Sözen 2012).

Artvin İli sınırları içinden geçen Çoruh Nehri üzerinde, il sınırları içinde 7 baraj (3 baraj faaliyete geçmiştir) projesi mevcuttur. Bu barajların inşaat ya da su toplama havzalarında, başta da Yusufeli ilçesi olmak üzere Ardanuç, Şavşat ve Merkez ilçenin bazı kısımları kalacak olmasından dolayı üretimi yapılan birçok ürün ve doğal florada bulunan 117 adet endemik tür gibi bitkisel kaynaklar kaybolma riski ile karşı karşıyadır (Anonim 2012). Artvin İli'nde biyolojik çeşitlilik sadece baraj nedeniyle değil bunun dışında sosyoekonomik problemler nedeniyle de tehdit altındadır. İı, bölgemizin en fazla göç veren noktası olup bu nedenle tarım alanları terk edilmektedir. Bu da özellikle yöresel birçok tarım ürününün kaybolma riskinin tüm il geneli için geçerli olduğunu göstermektedir (Sözen 2012).

$\mathrm{Bu}$ çalışmada, yukarıda bahsedilen gerekçeler doğrultusunda Artvin İlinin en önemli tarımsal ürünlerinden biri olan fasulye materyalinin kaybolmasına engel olmak için toplanıp özellikleri belirlenerek ileride yapılacak ıslah çalışmalarında kullanıımak ve ulusal gen bankasına teslim edilmek için yürütülmüştür.

\section{Materyal ve Yöntem}

Materyal toplamak için hedef bölgenin tespit edilmesi amacıyla Artvin Tarım ì Müdürlüğü kayıtları ile Master Planı ve teknik elemanların bilgilerinden faydalanılarak fasulye materyalinin toplanacağı alanlar tespit edilmiş, ilin kuru fasulye yetiştiren kısımları öncelikli olmakla birlikte ilde yapılan ve yapılacak olan 7 barajın altında kalacak alanlar ön plana çıkarılmaya çalışılmıştır. Tohum toplanacak duraklar önce kuru fasulye yetiştiriciliği yapılan ilçeler, sonra bunların sahip olduğu köy sayıları dikkate alınarak kademeli örnekleme yöntemine göre belirlenmiştir. Materyallerin toplandığı ilçe ve köy adları, toplanan materyal sayıları ile birlikte Çizelge 1'de verilmiştir. Bu köyler 24.04.2005-03.05.2005 tarihleri arasında ziyaret edilerek toplam 279 noktadan materyal toplanmıştır.

Çizelge 1. Yerel fasulye materyallerinin toplanıldığı ilçe ve köy adları

Table 1. The names of towns and villages where local bean materials were collected

\begin{tabular}{|c|c|c|}
\hline İlçe Adı & Köy Adları & $\begin{array}{c}\text { Toplanan Materyal } \\
\text { Sayısı }\end{array}$ \\
\hline Merkez & \multirow{7}{*}{$\begin{array}{l}\text { Ortaköy, Oruçlu*, Berta, Çimenli, Pırnarlı, Sakalar, Kalburlu, } \\
\text { Köseler, Bağcılar } \\
\text { Uğur, Uluköy, Ullukent, Dikyamaç, Sırtoba, Boyuncuk } \\
\text { A.Irmaklar, Tütünlü, Naldöken, Ferhatlı, Soğanlı, Gümüşhane, } \\
\text { Anaçlı, Peynirli, Aydın, Torbalı, İncilli } \\
\text { Demirciler } \\
\text { Damar, Güngören, Ardıçlı } \\
\text { Eskale, Dereiçi, Ciritdüzü, Cevizli, Kayadibi, Atalar, Çoraklı, } \\
\text { Susuz, Tepeköy, Küplüce, Çayağzı, Karaağaç, Kayabaş, } \\
\text { Çavdarlı, Üzümlü } \\
\text { Narlık, Yarbaşı, Esendal, Dokumacılar, Bahçeli, Bakırtepe, } \\
\text { Özgüven, Bademkaya, Çağlayan, Kılıçkaya, Tekkale, } \\
\text { Sebzeciler, Ormandibi, Irmakyanı, İnanlı, Boyalı, Bostancı, } \\
\text { Zeytincik, Çıralı, Öğdem, Serinsu, Sarıgöl, Çeltikdüzü, } \\
\text { Alanbaşı, İşan, Darıca, Yüncüler, Yağcılar }\end{array}$} & 26 \\
\hline Arhavi & & 16 \\
\hline Ardanuç & & 74 \\
\hline Borçka & & 2 \\
\hline Murgul & & 24 \\
\hline Şavşat & & 59 \\
\hline Yusufeli & & 78 \\
\hline & & 279 \\
\hline
\end{tabular}

Koyu renkle belirtilen köyler baraj altında kalan/kalacak olanlardır

*Villages written in bold are those which have been / will be flooded by dams 
Çizelge 2. Artvin İlinden toplanan yerel fasulye materyallerine ait pasaport bilgilerini içeren form Table 2. The form that contains pasaport information of local bean materials collected from Artvin

\begin{tabular}{|c|c|c|c|c|c|c|c|}
\hline \multicolumn{3}{|c|}{$\begin{array}{l}\text { TOPLAMAYI YAPAN EKIP: } \\
\text { TARIH : } \\
\text { ULLKE : } \\
\text { BÖLGE KODU : }\end{array}$} & \multicolumn{3}{|c|}{$\begin{array}{c}\text { TOPLAMA FORMU } \\
\text { İLI : } \\
\text { YÖRESI : }\end{array}$} & $\begin{array}{r}\text { ENLEM } \\
\text { BOYLAM }\end{array}$ & \\
\hline No & $\begin{array}{c}\text { Kaylt } \\
\text { No }\end{array}$ & $\begin{array}{c}\text { Botanik } \\
\text { No }\end{array}$ & $\begin{array}{c}\text { Yöresel } \\
\text { İsim }\end{array}$ & Örnek & Sıklık & $\begin{array}{c}\text { Külttür } \\
\text { Durumu }\end{array}$ & Habitat \\
\hline
\end{tabular}

Çizelge 3. Alt örneklerin toplandığı yerlere ait sınıflandırılmış rakımlar ve alt örnek sayıları

Table 3. The classified elevations and numbers of sub-samples regarding the places where sub-samples were collected

\begin{tabular}{|c|c|c|}
\hline Rakım $(\mathbf{m})$ & Alt Örnek Sayısı & $\%$ \\
\hline $0-500$ & 72 & 18 \\
$501-1000$ & 189 & 47 \\
$1001-1500$ & 93 & 23 \\
$1501-2000$ & 43 & 11 \\
$2001<$ & 3 & 1 \\
\hline Toplam (Total) & 400 & 100 \\
\hline
\end{tabular}

Toplanan 279 adet materyal tane renkleri ve şekilleri dikkate alınmak suretiyle alt örneklere ayrılmış ve 400 adet alt örnek oluşturulmuştur.

Yerel Fasulye materyallerinin toplanılması işlemi sırasında GPS (Global Possitioning System) aleti ile her bir toplama noktasının rakımları ve koordinatları belirlenerek formlar doldurulmuş ve bu formlar her bir toplama noktasına ait fasulye setleri ile birlikte ulusal gen bankasına teslim edilmiştir (Çizelge 2).

\section{Bulgular ve Tartışma}

Artvin Illi'nden 279 noktadan toplanan fasulye materyalinin tohum şekli ve rengine göre ayrılan alt örneklerin sayıları ile toplandıkları bölgelere ait sınıflandııımış rakımlar tablo halinde Çizelge 3'de verilmiştir. Çizelge 3 incelendiğinde toplam 400 adet alt örnekten 189 tanesinin (\% 47) 501-1.000 m arasındaki rakımlardan toplandığı görülürken $2.000 \mathrm{~m}$ üzerinde rakıma sahip olan köylerden toplanan alt örnek sayısının 3 adette kaldığı ve toplam örneklerin sadece \% 1'ini oluşturduğu tespit edilmiştir. Yapılan bir çalışmada (Özçelik ve Sözen) Kelkit Vadisi'nden toplanan 367 adet alt örneğin 4 tanesinin (\% 1.1) 0-500 m, 123 tanesinin (\% 33.5) 501-1000 m, 162 tanesinin (\% 44.1) 1001-1500 m, geriye kalan 78 tanesinin (\% 21.3) 1501-2000 m rakımlardan toplanıldığını belirlemişlerdir.

Tohum tipi ve şekline göre oluşturulan 400 adet yerel fasulye alt örneğinin tohum rengi bakımından beyaz, tek renkli ve çok renkli taneliler olmak üzere toplandıkları ilçeler bazında 3 sınıfa ayrılarak dağılımını gösteren tablo Çizelge 4'de verilmiştir.

Çizelge 4 incelendiğinde 400 adet alt örneğin 180 tanesinin ( $\%$ 45) beyaz tane rengine, 113 tanesinin (\% 28.25) tek renkli tohum rengine, geriye kalan 107 tanesinin (\% 26.75) ise çok renkli tohum rengine sahip olduğu tespit edilmiştir. Fasulyenin ana vatanı olan Güney Amerika ülkelerinden olan Küba'da yapılan çalışmada 328 materyal toplanmış ve bunların sadece \% 0.03'ünün beyaz taneli olduğu bildirilmiştir (Castineires et al. 1991). 
Çizelge 4. Artvin Illi'nden toplanan 400 adet fasulye alt örneğinin ilçelere ve tohum ana rengine göre dağılımı

Table 4. The distribution of 400 bean sub-samples collected in the Artvin province by districts and main testa color of the seeds

\begin{tabular}{|c|c|c|c|c|c|c|c|c|}
\hline \multirow[t]{2}{*}{ İlçeler } & \multicolumn{6}{|c|}{ Tane rengi yönünden alt örnekler } & \multirow[b]{2}{*}{ Toplam } & \multirow[b]{2}{*}{$\%$} \\
\hline & Beyaz & $\%$ & Tek Renkli Tane & $\%$ & Çok Renkli Tane & $\%$ & & \\
\hline Merkez & 22 & 12.3 & 10 & 8.8 & 10 & 9.4 & 42 & 10.5 \\
\hline Arhavi & 7 & 3.8 & 7 & 6.2 & 8 & 7.5 & 22 & 5.5 \\
\hline Ardanuç & 34 & 18.9 & 25 & 22.1 & 17 & 15.8 & 76 & 19 \\
\hline Borçka & 2 & 1.1 & 5 & 4.4 & 1 & 0.9 & 8 & 2 \\
\hline Murgul & 14 & 7.8 & 10 & 8.9 & 8 & 7.5 & 32 & 8 \\
\hline Şavşat & 40 & 22.2 & 17 & 15.1 & 29 & 27.1 & 86 & 21.5 \\
\hline Yusufeli & 61 & 33.9 & 39 & 34.5 & 34 & 31.8 & 134 & 33.5 \\
\hline Toplam & 180 & & 113 & & 107 & & 400 & \\
\hline
\end{tabular}

Kelkit Vadisi'nden toplanılan 321 adet fasulye alt örneğinin tanımlanması sonucunda 254 adedinin beyaz taneli (\% 79.12), geriye kalan 67 adedinin ise renkli taneli (\% 20.88) olduğu ortaya konulmuştur (Özçelik ve Sözen 2009).

180 adet beyaz taneli fasulye alt örneğinin 61 tanesinin (\% 33.9) Yusufeli ilçesinden toplandığı görülürken Borçka ilçesinden 2 adet (\% 1.1) beyaz taneli fasulye alt örneğinin toplandığı belirlenmiştir. Yine 220 adet tek ve çok renkli tane formunda fasulye alt örneğinin 73 tanesinin (\% 33.2) Yusufeli ilçesinden toplandığı görülmüştür. Tek renkli fasulye alt örneklerinin renk dağılımı incelendiğinde kahverengi, sarı, viole, kırmızı ve siyah tohum renginde oldukları ve geniş bir varyasyon gösterdikleri tespit edilmiştir.

Özçelik ve Sözen (2009) yaptıkları çalışmada Kelkit Vadisi'nden topladıkları 67 adet renkli taneli alt örneğin tohum rengi bakımından geniş bir varyasyon gösterdiğini ve renkli tanelilerde 6 adet tohum rengi grubunun olduğunu tespit etmişlerdir. Tohum rengi bakımından en fazla alt örneğe sahip grubun 35 adet (\% 52.23) alt örnek ile koyu sarı tohum rengi grubu olduğunu bunu 15 adet ile viole tohum rengi grubunun izlediğini ayrıca renkli taneli içinde tohum rengi kahverengi, sarı, kırmızı ve yeşil olan örneklerinde bulunduğunu ortaya koymuşlardır.

Artvin İli'nden toplanan 400 adet alt örnek, tohum şekli bakımından 4 skala (dairsel, dairesel-eliptik, eliptik ve böbrek) içinden dairesel-eliptik, eliptik ve böbrek skalalarını gösteren tohum şekline sahip alt örneklerden meydana geldiği belirlenmiştir. Nitekim 400 adet alt örneğin 285 tanesinin (\% 71.25) eliptik, 109 tanesinin (\% 27.25) böbrek, geriye kalan 6 tanesinin (\% 1.5) ise dairesel-eliptik tohum tipinde olduğu ortaya konulmuştur. Özellikle eliptik tohum tipinde olan alt örneklerden yapılacak seleksiyon çalışmalarında ülkemizde şeker tane tipinde 2 adet olan çeşit sayısına destek olunacak kadar varyasyonun olduğu belirlenmiştir. Kelkit Vadisi'nden toplanarak tohum tip ve tohum şekline göre sınıflaması yapılan fasulyelerin \% 56.6'sının dairesel-eliptik olduğu tespit edilmiştir (Özçelik ve Sözen 2009).

\section{Sonuç}

Artvin gibi geniş tarım alanları olmayan, topografik yapısı eğimli olan ve bu nedenlerle yoğun konvansiyel tarımın ve özellikle yeni çeşitlerin girişinin az olduğu coğrafyalar özellikle yerel materyallerin sürdürülebilirliği için özel öneme sahiptirler. Ancak bu materyaller ve biyolojik çeşitlilik Artvin'de kurulan/kurulacak barajlar, ülkenin bir başka yöresinden bir başka tehdit unsuru nedeniyle sürdürülebilir olmaktan çıkmaktadır. Ülke genelinde biyolojik çeşitlilik, tarım, orman, kamusal ve endüstriyel yerleşim vs. gibi alanların sınırları ya da kullanım öncelikleri belirlenmediği sürece bu kayıplar sürecektir. Ancak araştırıcı olarak üstümüze düşen bu kayıpların en aza inebilmesi için bu tür alanlarda materyal toplama ve koruma altına almak önceliklerimiz arasında yer almalıdır. Nitekim çalışmamız bu hedef için yola çıkmış ve materyal toplanarak bilgileri ile ulusal gen bankasına teslim edilmiştir.

$\mathrm{Bu}$ çalışmamızda topladığımız yerel fasulye materyalinin tohum görsel özellikleri dikkate alındığında bile çok zengin olduğu sonucuna varılmıştır. 
Ülkemizde tescil ettirilen yemeklik tane baklagillere ait standart çeşit sayısı yeterli sayıda değildir. Yerel materyallerden yeni çeşitlerin geliştirilmesi tarımda sürdürülebilirliğin temelini oluşturmaktadır. Yabancı tohum firmalarının piyasamızı tamamen ele geçirmesine müsaade etmemek için Artvin İli fasulyelerinde olduğu gibi kaynakların değerlendirilerek yeni çeşitlerin geliştirilmesine hız verilmelidir. Nitekim burada irdelenen çalışmadan elde edilen kaynaklarla yeni fasulye çeşitlerinin geliştirilmesine yönelik çalışmalarımız devam etmektedir.

\section{Kaynaklar}

Akçin A., 1988. Yemeklik Tane Baklagiller. Selçuk Üniversitesi Yayınları:43, Ziraat Fakültesi Yayınları:8, 377 s, Konya

Anonim, 2011. http://faostat.fao.org/ site/336/ DesktopDefault.aspx?PageID=336

Anonim, 2011. Artvin Tarım İ Müdürlüğü, http://artvintarim.gov.tr/ menulD=3\&page
Anonim, 2011. Türkiye İstatistik Kurumu, http://tuikapp.tuik.gov.tr/bitkiselapp/bitkisel.z ul

Anonim,2012.http://www.cografyaegitimi.biz/forum/ artvinin-iklimi-ve-bitki-ortusu-t2501.0.html

Castineiras L., Esquivel M., Lioiand L. and Hammer K., 1991. Origin, diversity and utilization ofthe Cuban germplasm of common bean Phaseolus vulgaris L.). Euphytica, 57:1 - 8.

Özçelik H. ve Sözen Ö., 2009. Kelkit Vadisi yerel fasulye (Phaseolus vulgaris L.) populasyonlarının toplanması, karakterizasyonu, morfolojik ve agronomik değişkenliklerin belirlenmesi. Proje No: 1080013, $80 \mathrm{~s}$, Ankara

Sözen Ö. 2012. Kelkit Vadisi ve Artvin İli'nden Toplanan Yerel Fasulye (Phaseolus vulgaris L.) Populasyonlarından Teksel Seleksiyon Metodu ile Şeker Tane Tipinde Çeşit Geliştirilmesi Üzerine Bir Araştırma. Doktora tezi, Ondokuz Mayıs Üniversitesi Fen Bilimleri Enstitüsü (Basılmamış), $105 \mathrm{~s}$, Samsun 